\title{
Non-breeding ecology of the Whinchat Saxicola rubetra in Nigeria
}

\author{
Buskskvättans Saxicola rubetra ekologi under övervintring i Nigeria
}

\author{
YAHKAT BARSHEP, ULF OTTOSSON, JONAS WALDENSTRÖM \& MARK HULME
}

\begin{abstract}
This study on the non-breeding ecology of the Whinchat Saxicola rubetra was conducted in central Nigeria from February through April. The core site was at Gwafan (N09 $53^{\prime}$, E08 $8^{\circ} 7^{\prime}$ ), an open scrubland located $10 \mathrm{~km}$ east of the city of Jos. The density of Whinchats at Gwafan was 0.58 individuals/ha, almost three times the overall density around Jos. Time budget observations of colour banded Whinchats, including six birds fitted with radio-transmitters, showed that they spent $80 \%$ of their time perching, $11 \%$ foraging, $7 \%$ preening, and $2 \%$ flying. The main method of catching insects was a swoop to the ground. There was no change in perching, preening or flying time but the time some Whinchats spent foraging increased towards the end of the study period. GPS positions of individuals showed that all birds held clearly demarcated territories and defended them against neighbours. Aggressive interactions were also recorded between Whinchats and other bird species. Three birds

colour-ringed in 2006 returned to the study site in 2007 and one occupied almost the same territory, indicating site fidelity.

Yahkat Barshep, A.P. Leventis Ornithological Research Institute, Jos, Nigeria (corresponding author, current address: Animal Demography Unit, University of Cape Town, Rondebosch 7701, Cape Town, South Africa.)Email: byahkat@ yahoo.com

Ulf Ottosson, A.P. Leventis Ornithological Research Institute, Jos, Nigeria

Jonas Waldenström, School of Natural Sciences, Linnaeus University, SE-391 82 Kalmar, Sweden and Otttenby Bird Observatory, Sweden

Mark Hulme, British Trust for Ornithology, The Nunnery, Thetford, Norfolk, UK
\end{abstract}

Received 8 March 2012, Accepted 27 March 2012, Editor : S. Svensson

\section{Introduction}

With more than 2.1 billion Palaearctic birds estimated to winter in sub-Saharan Africa (Hahn et al. 2009), it is apparent that many species depend on favourable situations in Africa for maintaining their status in Europe. This intercontinental migratory connectivity was emphasized after 1968, when a severe drought in the Sahel zone of West Africa was mirrored in massive declines in the returning numbers to Europe of common migrant species that winter in northern Sahel (Winstanley et al. 1974, Cowley 1979, Cavé 1983). In Britain, for example, the Common Whitethroat Sylvia communis dropped in numbers by $70 \%$ between 1968 and 1969 (Hjort \& Lindholm 1978, Marchant et al. 1990).

During the last four decades few papers on the non-breeding biology of Palaearctic birds have been published compared to the number produced relating to breeding biology studies in Europe. For instance, within Nigeria alone an estimated 75 million migrants are wintering (Elgood 1964, Elgood et al. 1966), but only a dozen or so studies on these birds have been published. The earliest publications from Marchant (1942), Rayner (1962), Brown (1964), Elgood et al. (1966) and Smith (1965), describes a situation that in large part has been altered in recent decades by rapid land changes due to alterations in agricultural practices, increased human population numbers, and massive deforestation of the dry savannah belts. A few recent studies point to the need for conducting more research in this region on all aspects from the density and distributions of migrants (e.g. Jones et al. 1996), intra- and inter-specific competition (Wilson \& Cresswell 2007), habitat selection (Vickery et al. 1999), migration and territoriality (Ottosson et al. 2005) and even the effects of shared parasites (Waldenström et al. 2002).

We studied the non-breeding biology of the Whinchat Saxicola rubetra in a Nigerian wintering area and report the results of two years' fieldwork on behaviour, territoriality, and a density survey. The Whinchat is a long-distance migrant that breeds in Eurasia and spends a considerable proportion of the non-breeding part of its annual 
cycle in sub-Saharan Africa. It is a ground-foraging passerine bird, inhabiting primarily cultivated grassland and open scrubland (Baillie et al. 2005) and the extent of occurrence in Africa is estimated at 4,600,000 $\mathrm{km}^{2}$ (Birdlife International 2006), stretching from Senegal to the Congo. Over the last decades drastic declines in numbers of many farmland bird species have been observed in Western Europe, a phenomenon linked to a decrease in arthropod availability due to the intensification of agriculture (Müller et al. 2005, Britschgi et al. 2006), the simplification of landscape structure and massive use of pesticides (Gillings \& Fuller 1998, Brickle et al. 2000, Robinson \& Sutherland 2002) coupled with nest loss (e.g. Tucker \& Heath 1994, Blaxter \& Robertson 1995). In Switzerland, the Whinchat is red-listed as it has disappeared almost completely from the lowlands (Keller et al. 2001) and it is currently among the top priority 50 bird species in Europe for which conservation plans are elaborated (Bollmann et al. 2002).

Within Nigeria, the species is an abundant winter visitor to the southern half of the country (Elgood 1964) and a passage migrant in the north except on the Jos Plateau where it appears to over-winter (Smith 1965). This study aims to examine the ecology of the Whinchat within the guinea savannah zone of the Jos Plateau, Nigeria. We examined the daily behaviour patterns and how they change over time, predicting that as time of migration approaches, birds will increase time spent foraging. We also examined territorial behaviours and estimated territory sizes, and estimated the density of Whinchats at the study site, comparing this with the estimated average density of Whinchats on the Jos Plateau.

\section{Method}

Study site

The study was carried out in Jos, North-central Nigeria (N09 $\left.56^{\prime}, \mathrm{E} 08^{\circ} 53^{\prime}\right)$. Jos is located within the Guinea savannah belt that is the wintering area of many Palearctic migrants (Moreau 1952, Salewski \& Jones 2006). The region is typically characterized by Savannah woodland but human activities have resulted in the extensive and severe degradation of the habitat. Remnants of the woodland are restricted to the steep and less accessible margins of the plateau, with open grassland occupying the remainder of the plateau (White 1983). The main site for this study is Gwafan (N09 $53^{\prime},{\mathrm{E} 08^{\circ}}^{\circ} 7^{\prime}$ ), an area of open scrubland interspersed by farmlands and a few ponds created by past mining activities.
Here, time budget observations, Whinchat density and territory behaviour were observed.

\section{Whinchat density}

Transect counts were conducted around the study site in Gwafan during the dry season between February and April 2004. 25 transects were surveyed with 24 of these repeated once. Transects were $100 \mathrm{~m}$ long and were arranged in a random fashion with at least $200 \mathrm{~m}$ between starting points to avoid transects overlapping. Transects were surveyed between dawn and 10am. Perpendicular distances to birds seen from the transect were recorded using a laser range-finder. Transects were re-visited in the afternoons and the number of trees over $3 \mathrm{~m}$ tall within $20 \mathrm{~m}$ either side of each transect was recorded. Bird densities were calculated using distance sampling in the program Distance 5.0 version 2 (CREEM, St Andrews 2008). Whinchat observations were truncated at $60 \mathrm{~m}$, the distance within which $95 \%$ of observations fell as detection decreased with distance from the transect (Buckland et al. 2001), and length of transect in metres was used as the measure of effort. A half normal model with no adjustments and total number of trees on the transect as a covariate was chosen using Akaike's Information Criterion (AIC) as the best detection function to fit the data. The overall Whinchat density on the Jos Plateau was estimated by one of the authors (Mark Hulme) in a separate study, using the same transect method

\section{Territory mapping}

This part of the study was carried out from February to April of 2006 and 2007 at Gwafan about $10 \mathrm{~km}$ east of the city of Jos. The core study area, about $1.5 \mathrm{~km}^{2}$, was visited almost daily. In 2006 , all birds but one observed within the core study area were trapped using a combination of mist-nets and claptraps. Seventeen Whinchats, 10 in 2006 and 7 in 2007 were caught and equipped with a numbered lightweight metal ring and three individual combinations of coloured rings. In 2007, six birds were fitted with Biotrack ${ }^{\circledR}$ tail-mounted radiotransmitters.

The territoriality and site fidelity of marked birds were estimated by recording the geographical positions of all marked birds within the area. Birds were either spotted using binoculars and a telescope (for colour-ringed birds) or detected by telemetry using a Biotrack ${ }^{\circledR}$ SIKA Radio tracking receiver connected to a Yagi Antenna. Bird positions were 
recorded using a Garmin ${ }^{\circledR}$ Geographic Positioning System (eTrex $\left.{ }^{\circledR} H\right)$. The positions were exported to a computer and plotted using the Home Range extension of ArcView ${ }^{\circledR}$ Geographic Information System (GIS) where the territory of each Whinchat was estimated using the Minimum Convex Polygon (95\% CI) method; only the territory of individuals with more than 15 GPS positions were calculated. Special aggressive interactions, such as chases and fights, with other Whinchats or other bird species were noted.

\section{Time-activity budgets}

We analysed the behaviour of Whinchats in the study area by making time-activity budget observations of all the colour-ringed individuals. In addition to observations on the ringed individuals, one unringed bird in 2006 and several unringed birds in 2007 were observed. Each individual was observed continuously for up to ten minutes and the duration of all activities within this time frame was recorded on a tape recorder (Martin \& Bateson 1993). To get an unbiased representation of activities likely to be carried out by the Whinchats at the time of observation, only time budgets of more than five minutes were used in the analysis. The activities noted were: A) Perching: regarded as the observation time between feeding attempts or when a bird stays on a perch without engaging in some obvious activity; B) Foraging: considered as the time a bird is seen chasing after a prey item, pecks continuously at a place on the ground or flies at a prey in the air irrespective of the success of the action; C) Flying: this is considered a separate activity from the flight associated with feeding if the bird simply moves from perch to perch; D) Preening: when the bird is preening its feathers. Aggressive interactions were observed but took an insignificant proportion of the total time. All birds were observed with a telescope from at least 50m away to avoid any kind of disturbance which might affect their behaviour. In addition, when an individual bird was being observed, the height of all perches used by that individual was measured at the end of the observation.

Hourly temperatures and wind speed data were obtained from a weather station (Vantage Pro2 weather station) at the nearby A. P. Leventis Ornithological Research Institute located $5 \mathrm{~km}$ from the study site. Statistica $8 \circledR$ was used for statistical analyses. For General Linear Model (GLM) analyses, data were transformed using Box-Cox transformation (Box \& Cox 1964) to meet the condition of normal distribution. GLM analyses examining the change in the proportion of time spent on foraging, flying and preening over time (date from 1 February) were performed with hourly wind velocity and temperature $\left({ }^{\circ} \mathrm{C}\right)$ as covariates and individuals as random factor to account for non-independence in the data due to repeated observations on the same individuals. The model also included two-way interactions of variables.

\section{Results}

\section{Whinchat density}

The overall density of Whinchats on the Jos Plateau was 0.21 individuals/ha ( 0.18 to $0.2495 \%$ C.I.). At Gwafan Whinchat density was estimated at 0.51 individuals/ha (0.33 to $1.0395 \%$ C.I.), higher than the average density on the Jos plateau. Because there were few trees at Gwafan, Whinchat density at this site was not significantly correlated with tree density.

Table 1. Dates when individual Whinchats were first ringed and last seen at Gwafan in Jos, Nigeria and estimates of their respective home ranges.

Datum för olika buskskvättors vistelse vid Gwafan, Jos, Nigeria samt storleken av deras hemområden.

\begin{tabular}{rrccr}
\hline Year & Id & $\begin{array}{c}\text { First ringed } \\
\text { Ringmärkt }\end{array}$ & $\begin{array}{c}\text { Last seen } \\
\text { Sist sedd }\end{array}$ & Area $\left(\mathrm{m}^{2}\right)$ \\
\hline 2006 & 1 & 07-Feb & 10-Apr & 3556 \\
& 2 & 08-Feb & 17-Apr & 2182 \\
& 3 & 09-Feb & 15-Feb & \\
& 4 & 09-Feb & 13-Apr & 962 \\
& 5 & 09-Feb & 07-Apr & 1890 \\
& 6 & 09-Feb & 21-Apr & 4697 \\
& 7 & 10-Feb & 18-Apr & 758 \\
& 8 & 22-Feb & 17-Apr & 823 \\
& 9 & 08-Mar & 18-Apr & 866 \\
& 10 & 20-Mar & 18-Apr & 4575 \\
& 11 & 21-Mar & 21-Apr & 358 \\
\hline 2007 & 12 & 07-Feb & 10-Apr & 2286 \\
& $2 *$ & 07-Feb & 13-Feb & \\
& $5^{*}$ & 07-Feb & 20-Feb & \\
& $10^{*}$ & 07-Feb & 21-Apr & 7709 \\
& 13 & 08-Feb & 28-Mar & 3986 \\
& 14 & 08-Feb & 29-Mar & 5645 \\
& 15 & 08-Feb & 21-Feb & 5261 \\
16 & 08-Feb & 08-Mar & 2995 \\
\hline
\end{tabular}

*Birds that were caught in 2006 and re-sighted at the study area in 2007.

*Fåglar som fångades 2006 och återsågs $i$ området 2007. 


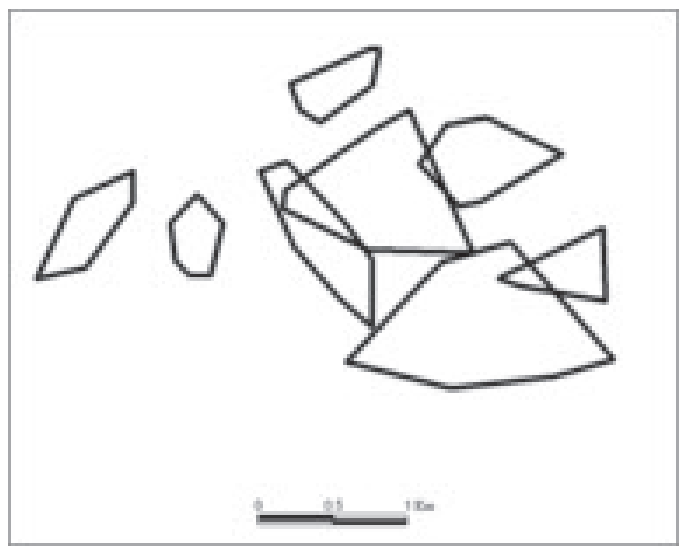

Figure 1. Home ranges of seven Whinchats in Jos, Nigeria (2006) plotted using the Minimum Convex Polygon method from GPS positions.

Hemområden för sju buskskvättor i Jos, Nigeria (2006) plottade med minsta konvexa polygonmetoden från GPSpositioner.

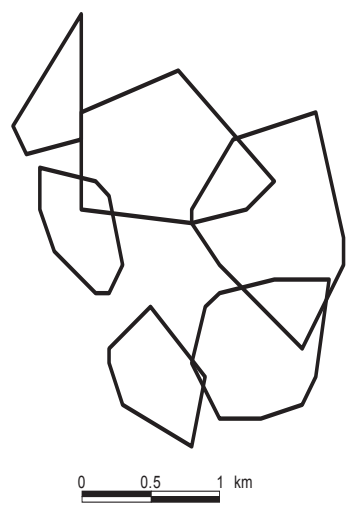

Figure 2. Home ranges of seven Whinchats in Jos, Nigeria (2007) plotted using the Minimum Convex Polygon method from GPS positions.

Hemområden för sju buskskvättor i Jos, Nigeria (2007) plottade med minsta konvexa polygonmetoden från GPSpositioner.

\section{Territoriality and site fidelity}

Whinchats usually arrive in Nigeria sometime in mid-September (Elgood et al. 1966) so that by the time this study commenced in February, birds had already arrived and settled into territories (Table 1). Of the 11 individuals (ten ringed, one unringed) observed in 2006, only one left the study site within five days of capture. All others were present until 7 April when the first Whinchat left the site, presumably on the first leg of northward migration and

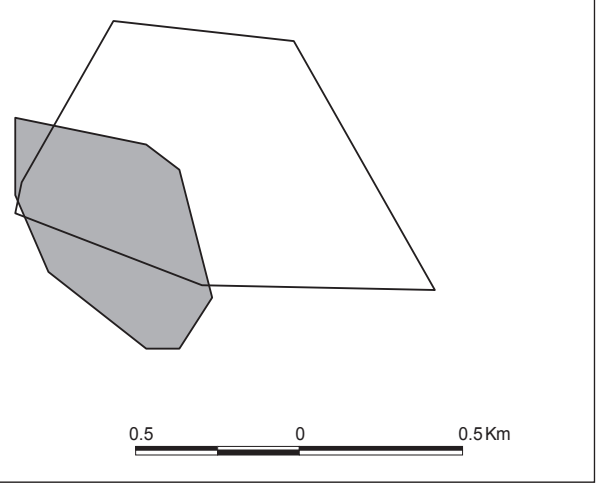

Figure 3. The home range of an individual bird occupied in 2006 (grey pentagon) which returned to the same site in 2007 (open pentagon)

Hemområden för en buskskvätta 2006 (grått) som återvände till samma plats 2007 (vitt).

the last ringed individual seen was on 21 April. In 2007, however, the turnover of individuals at the site was higher. Of the seven individuals ringed, only three were still present at the site at the beginning of April. Three birds ringed in 2006 returned to the study site in 2007, though two stayed for only seven and 13 days and were not seen again in the study area.

Radio-tracked birds moved predominantly within an area that overlapped little with the areas utilised by other birds (Figure 1 and Figure 2). In 2006, the mean territory size was $2067 \mathrm{~m}^{2}$ (range 358-4697 $\mathrm{m}^{2}, \mathrm{n}=10$ ), which was significantly smaller compared to the territories in 2007 when birds occupied on average $4647 \mathrm{~m}^{2}$ (range: $2286-7709 \mathrm{~m}^{2}, \mathrm{n}=6$; $\mathrm{t}$ $=2.82, \mathrm{p}<0.01$ ). One Whinchat that returned to the study site in 2007 occupied almost the same area as in 2006 (Figure 3).

During the course of the study in 2006, nine aggressive interactions were recorded between the Whinchats. These consisted mainly of swift chases between birds occupying neighbouring territories but sometimes by fights $(\mathrm{n}=3)$. In addition, interspecific interactions between Whinchat and Northern Wheatear Oenanthe oenanthe (3), Woodchat Shrike Lanius senator (2) and Crested Lark Galerida cristata (1) were observed. In 2007, five intraspecific aggression interactions were observed, in addition to inter-specific aggression between the Whinchat and Northern Wheatear (4) and Common Whitethroat Sylvia communis (1). 
Time-activity budgets and foraging behaviour

In total we collected 193 time-activity budget observations totalling 1022 minutes of observations: 70 in February, 81 in March and 42 in April. These were observations from both ringed and un-ringed birds although observations from un-ringed birds were excluded from the GLM analyses. There was no statistical difference in foraging $(\mathrm{t}=0.84$, $\mathrm{p}=0.40, \quad \mathrm{df}=193)$, preening $(\mathrm{t}=-0.70, \mathrm{p}=0.47$, $\mathrm{df}=193)$ and flying $(\mathrm{t}=1.29, \mathrm{p}=0.21, \mathrm{df}=163)$ activities between the two years, so data were pooled for the further analyses. On average Whinchats spent $80 \%$ of their time perching, $11 \%$ foraging, $7 \%$ preening and $2 \%$ flying. The trend in the proportion of time spent foraging over the study period varied between individuals $\left(\mathrm{F}_{1,165}=3.84, \mathrm{p}=0.042\right)$. There was an increasing trend in the percentage time spent foraging in six birds, a decreasing trend in two birds, and no trend in six birds.

The percentage time allocated for foraging increased from the start of the study in February to when it ended in April, although this increase was borderline significant (Table 2). Foraging time increased with increase in mean hourly temperature and decreased with hourly wind velocity (Table 2 ). The interaction term of (date*mean daily temperature) was not significant $\left(\mathrm{F}_{1,165}=3.63, \mathrm{p}=0.05\right.$, $b=-0.004)$, neither was the interaction term (date*mean hourly wind velocity) $\left(\mathrm{F}_{1,165}=3.04\right.$, $p=0.08, b=0.01$ ), showing that the effect of temperature and wind on foraging activity was the same throughout the study period. The proportion of time spent preening increased significantly with an increase in the hourly wind velocity (Table 2), but the proportion of time spent preening over the study period varied between the focal study birds as indicated by the significant interaction of (Individual ID*date) $\left(\mathrm{F}_{1,165}=1.84, \mathrm{p}=0.03\right)$. Flying and perching time did not change significantly with respect to date neither were they affected by hourly temperature nor wind speed (Table 2).

Birds were often seen perched on the highest bushes where they had a clear view of the ground. Mean perch height was $1.03 \mathrm{~m}$ (Range 0.5-1.8 $\mathrm{m}, \mathrm{n}=203$ ). Feeding behaviour usually involved a period of observation from a perch followed by a swooping flight to the ground to catch prey. There were only three observations of prey being caught in mid-air, compared to 103 of prey taken on the ground. No quantitative data on food availability or diet were collected but during time budget observations, there were five observations of birds feeding on caterpillars (Lepidoptera), 29 on ants (Hymenoptera), six on grasshoppers (Orthoptera), twice on antlions (Neuroptera), and eight times on berries of Lantana camara (Verbenaceae) which were fruiting at the time of the study.

\section{Discussion}

\section{Territorial behaviour and density}

Following colour-ringed birds and those equipped with transmitters, it was evident that the Whinchats held and defended well-defined territories during the non-breeding season. From the time birds were ringed in February to the 13th of March, there were no non-territorial birds. From 13th March, a few unringed birds were noticed; likely birds from further south making their way northward on passage to the edge of the Sahara (Elgood et al. 1966). Because they were un-ringed and non-territorial, it was not possible to estimate how long these birds

Table 2. GLM result to examine proportion of time spent flying, foraging, preening, and perching by the Whinchats over the whole study period (February - April) controlling for average hourly temperature $\left({ }^{\circ} \mathrm{C}\right)$ and wind velocity from 0700. Dependent variable: total foraging time of all Whinchats each day, Random factor: Individuals' Id, b: parameter estimate.

GLM resultat för analys av andelen tid som buskskvättorna använde för flygning, födosök, fjädervård och stillasittande, kontrollerad för temperatur och vindhastighet. Beroende variabel: totala födosökstiden för alla fäglar varje dag; slumpfaktor: individens Id, b: parameterskattning.

\begin{tabular}{|c|c|c|c|c|c|c|c|c|c|c|c|c|}
\hline & \multicolumn{3}{|c|}{ Forage Födosök } & \multicolumn{3}{|c|}{ Preen Fjädervård } & \multicolumn{3}{|c|}{ Fly Flygning } & \multicolumn{3}{|c|}{ Perch Sittande } \\
\hline & F & $\mathrm{p}$ & $\mathrm{b}$ & $\mathrm{F}$ & $\mathrm{p}$ & $\mathrm{b}$ & $\mathrm{F}$ & $\mathrm{p}$ & $\mathrm{b}$ & $\mathrm{F}$ & $\mathrm{p}$ & $\bar{b}$ \\
\hline Date & 3.82 & 0.05 & 0.1 & 0.04 & 0.82 & -0.00 & 0.00 & 0.96 & 0.00 & 0.58 & 0.44 & -146.01 \\
\hline $\begin{array}{l}\text { Mean hourly } \\
\text { temperature } \\
\text { Mean hourly }\end{array}$ & 4.55 & 0.03 & 0.38 & 1.2 & 0.27 & -0.1 & 0.1 & 0.74 & -0.01 & 0.5 & 0.47 & 1015.41 \\
\hline wind speed & 7.2 & 0.01 & -1.72 & 3.94 & 0.04 & 0.53 & 0.12 & 0.72 & 0.02 & 2.34 & 0.12 & 7478.14 \\
\hline Individual ID & 0.75 & 0.74 & & 1.23 & 0.24 & & 1.51 & 0.09 & & 0.99 & 0.46 & \\
\hline
\end{tabular}


stayed at the site. Although the boundaries of territories were not sharply demarcated, each bird clearly had its own area of occupancy separated from that of its neighbours. These territories were defended against neighbouring birds by displays of aggressive behaviour consisting of swift chases and fights between the birds.

Dejaifve (1994) found that Whinchats in Zaire (now Democratic Republic of Congo) were territorial, occupying territories averaging $4,000 \mathrm{~m}^{2}$ and density averaged 0.8 individuals/ha. This density is within the $95 \%$ confidence limits for Whinchat density observed at Gwafan, although the overall Whinchat density on the Jos Plateau appears to be significantly lower than that found on the core study area, suggesting that the open scrub habitat at Gwafan is better suited to over-wintering Whinchats. We cannot say for certain why the densities of whincats at Gwafan were higher than the estimated overall density for the Jos Plateaau but one possible reason for the higher densities at Gwafan compared to the other habitat types is the characteristic moist and open scrubland at this site, which is similar to the habitats occupied by the Whinchats in Europe (Cramp 1988).

\section{Site fidelity}

In 2007, the return of 3 birds out of 10 birds ringed in 2006 to the same site demonstrates substantial site fidelity since the annual mortality rate of migrants is likely to be around 50\% (Sandercock \& Jaramillo 2002, Sillett \& Holmes 2002, Stokker et al. 2005). Fidelity to an overwintering site has been well documented in some migratory birds (McNeil 1982, Holmes et al. 1989, Latta \& Faaborg 2001) and is usually an indication of adequate resources within a site to an over-wintering bird in the previous season. However, changes in land use practice and habitat loss could ultimately translate to changes in food availability and when areas of habitat are lost, bird numbers often change accordingly (Gibbons et al. 1993, Norris 2005). There was an observed increase in human activity at the study site in 2007, compared with 2006; two buildings were under construction within the study site, and during this time the vegetation was burnt once and some shrubs were removed for fuel wood, reducing the available area for the Whinchats. This may be the reason why only three out of the originally ringed seven Whinchats were still present at the site at the end of the study in 2007.

\section{Foraging behaviour}

There was an overall increasing trend in the proportion of time spent foraging as the time for spring migration approached although this result was borderline non-significant. This might be because different individuals showed varied trends in time spent foraging. However, the increasing trend in the proportion of foraging time is an indication that birds do try to increase their fat load as migration period approaches. Further studies which examine monthly weight of birds as well as fat stores will be necessary to confirm our prediction. However, it is noteworthy to mention that the cutting of shrubs for firewood, burning of the vegetation, and construction work would likely reduce the quality of the habitat, which could eventually translate into a loss of food. When food becomes scarce, birds will have to increase time spent foraging in order to meet their daily energetic requirements.

Some conservation implications are that the loss of a habitat could have a carry-over effect on individual fitness, which would eventually translate to the population level. As is typical of developing countries, the human population growth in Plateau state (largely identical with the Jos plateau) has put a major strain on resources through urban growth. A major threat to the environment is habitat loss and modification through agricultural intensification, overgrazing, uncontrolled bush burning and removal of woody plants for firewood (WWF 2007). Reduction in habitat translates to a reduction in resources, which is reflected in a lowered return rate. Eventually, the ability of the individuals to persist would depend on the availability and carrying capacity of suitable habitats elsewhere.

\section{Acknowledgements}

We thank the Swedish Ornithological Society and Lindgren's foundation for funding this project, staff of the A. P. Leventis Ornithological Research Institute especially Dr. Mwansat and Dr. S. Manu for logistic support, M. Samuel for her valuable help in the field, and Azi for helping with transport to the site, and Dr P. Jones and Dr S. Bensch for comments on an earlier draft. This is contribution no. 253 from Ottenby Bird Observatory and no. 51 from A. P. Leventis Ornithological Research Institute. This study was carried out in compliance with the current laws of the country in which it was conducted. 


\section{References}

Baillie, S. R., Marchant, J. H., Crick, H. Q. P., Noble, D. G., Balmer, D. E., Beaven, L. P., Coombes, R. H., Downie, I. S., Freeman, S. N., Joys, A. C., Leech, D. I., Raven, M. J., Robinson, R. A. \& Thewlis, R. M. 2005. Breeding Birds in the Wider Countryside: their conservation status 2004. BTO Research Report 385. British Trust for Ornithology, Thetford.

BirdLife International. 2006. Species factsheet: Saxicola rubetra. Available via DIALOG. http://www.birdlife.org. Accessed 2007.

Blaxter, K. \& Robertson, N. 1995. From Dearth to Plenty: The Second Agricultural Revolution. Cambridge University Press, Cambridge.

Bollmann, K., Keller, V., Müller, W. \& Zbinden, N. 2002. Prioritäre Vogelarten für Artenförderungsprogramme in der Schweiz. Ornit. Beob. 99: 301-320.

Box, G. E. P. \& Cox, D. R., 1964. An analysis of transformations. J. R. Stat. Soc. B. 26: 211-234.

Brickle, N. W., Harper, D., Aebischer, N. \& Cockayne, S. 2000. Effects of agricultural intensification on the breeding success of corn buntings Miliaria calandra. J. Appl. Ecol. 37: 742-755.

Britschgi, A., Spaar, R. \& Arlettaz, R. 2006. Impact of grassland farming intensification on the breeding ecology of an indicator insectivorous passerine, the Whinchat Saxicola rubetra: Lessons for overall Alpine meadowland management. Biol. Cons. 193-205.

Brown, A. P. 1964. Palaearctic migrants in West Africa. Nigerian Field 29: 174-177

Buckland, S. T., Anderson, D. R., Burnham, K. P., Laake, J. L., Borchers, D. L. \& Thomas, D. L. 2001. Introduction to Distance Sampling. Estimating Abundance of Biological Populations. Oxford University Press, Oxford.

Cavé, A. I. 1983. Purple Heron survival and drought in tropical West Africa. Ardea 71: 217-224.

Cowley, E. 1979. Sand Martin population trends in Britain, 1965- 1978. Bird Study 26: 113-116.

Cramp, S. 1988. The Birds of the Westem Palearctic Vol. V. Oxford University Press, Oxford.

Dejaifve, P. A. 1994. Ecology and behaviour of a palearctic migrant in Africa - The wintering of the Whinchat Saxicola rubetra in the Zaire and its winter distribution in Africa. Rev. ecol-terre vie 49: 35-52.

Elgood, J. H. 1964. Palearctic Migrants in Nigeria. Ibis 108: 84-116.

Elgood, J. H., Sharland, R. E. \& Ward, P. 1966. Palearctic migrants in Nigeria. Ibis 108: 84-116.

Gibbons, D. W., Reid, J. B. \& Chapman, R. A. 1993. The New Atlas of Breeding Birds in Britain and Ireland: 198891. Poyser, London.

Gillings, S. \& Fuller, R. J. 1998. Changes in bird populations on sample lowland English farms in relation to loss of hedgerows and other non-crop habitats. Oecologia 116: 120-127.

Hahn, S., Bauer, S. \& Liechti, F. 2009. The natural link between Europe and Africa-2.1 billion birds on migration. Oikos 118: 624-626.

Hjort, C. \& Lindholm, C-G. 1978. Annual bird ringing totals and population fluctuations. Oikos 30: 387-392.

Holmes, R. T., Sherry, T. W. \& Reitsma, L. 1989. Population structure, territoriality and overwinter survival of two migrant warbler species in Jamaica. Condor 91: 545-561.
Jones, P., Vickery, J., Holt, S. \& Cresswell, W. 1996. A preliminary assessment of some factors influencing the density and distribution of Palaearctic passerine migrants wintering in the Sahel zone of West Africa. Bird Study 43: 73-84.

Keller, V., Zbinden, N., Schmid, H. \& Volet, B. 2001. Rote Liste der gefährdeten Brutvogelarten der Schweiz. Swiss Federal Office for the Environment and Swiss Ornithological Institute, Bern and Sempach. Available via DIALOG. http://www.vogelwarte.ch/home.php?lang=e\&cap =voegel\&subcap=roteliste. Accessed 12 May 2009.

Latta, S. C. \& Faaborg, J. 2001. Winter site fidelity of Prairie Warblers in the Dominican Republic. Condor 103: 455468.

Marchant, S. 1942. Some birds of Owerri Province, S. Nigeria. Ibis 84: 137-198.

Marchant, I. H., Hudson, R., Carter, S. P. \& Whittington, P. A. 1990. Population Trends in British Breeding Birds. British Trust for Ornithology, Tring.

Martin, P. \& Bateson, P. 1993. Measuring Behaviour: An Introductory Guide. Cambridge University Press, Cambridge.

McNeil, R. 1982. Winter resident repeats and returns of austral and boreal migrant birds banded in Venezuela. $J$. Field Ornithol. 53: 125-132.

Moreau, R. E .1952. A place of Africa in the Palearctic migration system. J. Anim. Ecol. 21: 250-271.

Müller, M., Spaar, R., Schifferli, L. \& Jenni, L. 2005. Effects of changes in farming of subalpine meadows on a grassland bird, the Whinchat Saxicola rubetra. J. Ornithol. 146: 14-23.

Norris, D. R. 2005. Carry-over effects and habitat quality in migratory populations. Oikos 109: 178-186.

Ottosson, U., Waldenström, J., Hjort, C, \& McGregor, R. 2005. Garden Warbler Sylvia borin migration in subSaharan West Africa: phenology and body mass changes. Ibis 147: 750-757.

Rayner, M. 1962. Palaearctic birds in southern Nigeria. Ibis 104: 415-416.

Robinson, R. A. \& Sutherland, W. 2002. Post-war changes in arable farming and biodiversity in Great Britain. J. Appl. Ecol. 39: 157-176.

Salewski, V. \& Jones, P. 2006. Palearctic passerines in Afrotropical environments: a review. J. Ornithol. 147: 192-201.

Sandercock, B. K. \& Jaramillo, A. 2002. Annual Survival Rates of Wintering Sparrows: Assessing Demographic Consequences of Migration. Auk 199: 149-165.

Sillett, T. S. \& Holmes, R. T. 2002. Variation in survivorship of a migratory songbird throughout its annual cycle. $J$. Anim. Ecol. 71: 296-308.

Smith, V. W. 1965. Palaearctic migrants at Vom, Plateau Province, over five seasons. Bull. Nig. Orn. Soc. 6: 26-34.

Stokke, B. G., Møller, A. P., Sæther, B-E., Rheinwald, G. \& Gutscher, H. 2005. Weather in the Breeding Area and during Migration Affects the Demography of a Small Long -Distance Passerine Migrant. Auk 122: 637-647.

Tucker, G. M. \& Heath, M. F. 1994. Birds in Europe: their conservation status. BirdLife International, Cambridge.

Vickery, J., Rowcliffe, M., Cresswell, W., Jones, P. \& Holt, S. 1999. Habitat selection by Whitethroats Sylvia communis during spring passage in the Sahel zone of northern Nigeria. Bird Study 46: 348-355. 
Waldenström, J., Bensch, S., Kiboi, S., Hasselquist, D. \& Ottosson, U. 2002. Cross-species infection of blood parasite between resident and migratory songirds in Africa. Mol. Ecol. 11: 1545-1554.

White, F. 1983. The vegetation of Africa, a descriptive memoir to accompany the UNESCO/AETFAT/UNSO Vegetation Map of Africa. UNESCO, Paris.

Wilson, J. M. \& Cresswell, W. R. L. 2007. Identification of potentially competing Afrotropical and Palaearctic bird species in the Sahel. Ostrich 78: 363-368.

Winstanley, D. R., Spencer, R. \& Williamson, K. 1974. Where have all the Whitethroats gone? Bird Study 21: $1-14$.

World Wildlife Fund. 2007. Jos Plateau forest-grassland mosaic. - In: Cutler J. C. (ed.) Encyclopedia of Earth. Washington, D.C. Available via DIALOG. http://www. eoearth.org/article/Jos_Plateau_forest-grassland_mosaic. Accessed 19 May $200 \overline{8}$.

\section{Sammanfattning}

Mer än två miljarder fåglar från Europa flyttar till tropiska Afrika. Vad som händer under övervintringen är därför av största betydelse för de häckande beståndens storlek och utveckling. Men jämfört med de otaliga studierna av häckningsbiologin finns det förhållandevis få studier från vinterkvarteren. Det gäller exempelvis för de uppskattningsvis 75 miljoner vintergästerna i Nigeria.

I denna uppsats rapporterar vi resultaten från en studie av buskskvättans ekologi under vistelsen i Nigeria perioden februari till april åren 2006 och 2007. Studien genomfördes i den biotop som kallas Guinea-savann, i vilken många flyttare tillbringar vintern och där buskskvättan är vanlig. Undersökningsområdet var en och en halv kvadratkilometer stort och låg vid Gwafan nära staden Jos. Området är relativt hårt exploaterat av jordbruk, men en del restbiotoper finns.

Vi arbetade såväl med linjetaxeringar för att bestämma tätheten av buskskvättor som med märkta fåglar för att studera deras revirförhållanden och tidsbudget. De märkta fåglarna hade en metallring och individuella kombinationer av tre färgringar samt små radiosändare. De följdes antingen med kikare eller med radiomottagare och deras positioner registrerades med GPS. Tidsstudier gjordes både på sådana individmärkta fåglar som på en del icke märkta. Tidsåtgången för fyra aktiviteter noterades: stillasittande (vanligen spaning mellan bytesfångster), födosök (förföljde byte, hackade på marken eller flög mot ett byte oberoende av om det fångades eller ej), flygning (av annat slag än i samband med jakt) samt fjädervård. Aggressioner med andra fåglar förekom, men var tidsmässigt utan betydelse.
Tätheten av buskskvättor på Jos-platån i allmänhet var 0,21 individer per hektar. I vårt undersökningsområde var tätheten klart högre, nämligen 0,51 . Buskskvättorna kommer normalt till Nigeria i mitten av september och när vår studie började $\mathrm{i}$ februari hade de redan etablerat sina revir. Tiderna för deras vistelse framgår av Tabell 1. Av fåglarna från 2006 var det bara en som lämnade området efter ett fåtal dagar. Övriga stannade till april då de flyttade norrut, mellan 7 och 21 april. 2007 gav sig några av fåglarna iväg litet tidigare. Tre av fåglarna från 2006 återkom 2007, en av dem till nästan samma revir. De kartlagda reviren visas i Figur 1-3 och revirens storlek anges i Tabell 1. Medelstorleken var 2067 (358-4697) kvadratmeter 2006 och 4647 (2286-7709) 2007, alltså mer än dubbelt så stora det senare året. Figur 3 visar de delvis överlappande reviren för en av fåglarna.

Tidsstudien, baserad 193 tillfällen om tillsammans 1022 minuter, ungefär lika fördelade de tre månaderna, visade att buskskvättorna använde $80 \%$ av tiden till att sitta stilla, $11 \%$ till födosök, $7 \%$ till fjädervård och $2 \%$ till att förflytta sig flygande. Testerna enligt Tabell 2 visar att det var signifikanta effekter på födosök av temperatur och vindstyrka och på fjädervård av vindstyrka medan tiden för stillasittande och förflyttningar inte påverkades av någon av de studerade variablerna.

Sammanfattningsvis kunde vi således konstatera att buskskvättorna höll väl definierade och långvariga revir samt att det fanns en viss tendens till revirtrohet mellan åren. Huruvida våra tätheter är normala för liknande terräng i det stora vinterområdet vet vi inte, men det finns en uppgift från Kongo på 0,8 individer per hektar. Orsaken till att fåglarna 2007 inte stannade på samma sätt som 2006 kan ha varit mera omfattande störningar och att det skedde viss buskröjning och bränning som minskade den gynnsamma arealen. På Josplatån sker befolkningsökning och intensifiering av jordbruket och även annan exploatering. Detta gör att biotoperna kommer att bli sämre för buskskvättorna, vilket i sin tur ställer större krav på att ha tid till födosök, vilken vi visat kan påverkas av omvärldsfaktorer som temperatur och vind. Försämras förhållandena kraftig innebär det minskade möjligheter att samla på sig fett för flyttningen norrut och minskad överlevnad, fenomen som redan observerats hos flera arter i samband med biotopförsämringar orsakade av torrår. 